\section{Sign-Determination of Spin-Spin Coupling Constants in tert-Butylphosphaalkyne}

\author{
Bernd Wrackmeyer* \\ Laboratorium für Anorganische Chemie \\ der Universität Bayreuth, \\ Postfach 101251 , D-W-8580 Bayreuth
}

Z. Naturforsch. 47b, 437-438 (1992);

received September 17, 1991

Phosphaalkynes, Coupling Constants, NMR${ }^{1} \mathrm{H}\left\{{ }^{31} \mathrm{P}\right\}$ Hetronuclear Double Resonance,

Two-dimensional (2D) ${ }^{13} \mathrm{C} /{ }^{1} \mathrm{H}$ Heteronuclear Shift Correlations

The signs of the coupling constants ${ }^{1} J\left({ }^{31} \mathrm{P} \equiv{ }^{13} \mathrm{C}\right)$ $(>\mathrm{O}),{ }^{2} J\left({ }^{31} \mathrm{P}^{13} \mathrm{C}\right) \quad(>\mathrm{O}),{ }^{3} J\left({ }^{31} \mathrm{P}^{13} \mathrm{C}\right)(>\mathrm{O})$ and ${ }^{4} J\left({ }^{31} \mathrm{P}^{1} \mathrm{H}\right)(>\mathrm{O})$ in tert-butyl-phosphaalkyne (1) were determined by selective ${ }^{1} \mathrm{H}\left\{{ }^{31} \mathrm{P}\right\}$ NMR experiments and two-dimensional (2D) ${ }^{13} \mathrm{C} /{ }^{1} \mathrm{H}$ heteronuclear shift correlations based on ${ }^{n} J\left({ }^{13} \mathrm{C}^{1} \mathrm{H}\right)$ ( $n=1,2,3)$, confirming the previously assumed positive sign of ${ }^{1} J\left({ }^{31} \mathrm{P} \equiv{ }^{13} \mathrm{C}\right)$ in phosphaalkynes.

The convenient synthesis of kinetically stabilized phosphaalkynes such as the tert-butylphosphaalkyne (1) [1] has played a major role in the development of an enormously rich chemistry [2].

$$
\begin{gathered}
\left(\mathrm{CH}_{3}\right)_{3} \mathrm{C}-\mathrm{C} \equiv \mathrm{P} \\
\mathbf{1}
\end{gathered}
$$

Among other physical methods, ${ }^{1} \mathrm{H},{ }^{13} \mathrm{C}$ and ${ }^{31} \mathrm{P}$ NMR measurements have served from the beginning for the characterization of phosphaalkynes and, consequently, a wealth of data is available now [1-3]. Recently, ${ }^{13} \mathrm{C}$ and ${ }^{31} \mathrm{P}$ NMR data of phosphaalkynes were correlated with corresponding ${ }^{13} \mathrm{C}$ and ${ }^{15} \mathrm{~N}$ NMR parameters of nitriles [4]. As one of the results, it was concluded, on the basis of the linear correlation between coupling constants ${ }^{1} J\left({ }^{15} \mathrm{~N} \equiv{ }^{13} \mathrm{C}\right)$ and ${ }^{1} J\left({ }^{31} \mathrm{P} \equiv{ }^{13} \mathrm{C}\right)$, that the sign of ${ }^{1} J\left({ }^{31} \mathrm{P} \equiv{ }^{13} \mathrm{C}\right)$ should be positive [4]. Here, we confirm this assumption by the experimental sign-determination of ${ }^{1} J\left({ }^{31} \mathrm{P} \equiv{ }^{13} \mathrm{C}\right)$ in compound $\mathbf{1}$.

Relative signs of coupling constants are determined most conveniently by applying various double resonance techniques. The spin system under consideration must contain at least three spins, e.g., ${ }^{31} \mathrm{P},{ }^{13} \mathrm{C}$ and ${ }^{1} \mathrm{H}$ (see Scheme I), of which one functions as the so-called passive spin while resonances of the other two spins are either observed or irradiated [5]. In order to obtain the absolute signs, one absolute sign of a "key" coupling con-

\footnotetext{
* Requests for reprints to Prof. Dr. B. Wrackmeyer.

Verlag der Zeitschrift für Naturforschung, D-W-7400 Tübingen

0932-0776/92/0300-0437/\$01.00/0
}

stant has to be known. In the case of compound $\mathbf{1}$, it can be safely assumed that ${ }^{1} J\left({ }^{13} \mathrm{C}^{1} \mathrm{H}\right)>\mathrm{O}[6]$ and the absolute signs of all coupling constants involving the ${ }^{31} \mathrm{P}$ nucleus can be determined by four different heteronuclear double resonance experiments as shown in Scheme I.

The starting point is provided by a selective ${ }^{1} \mathrm{H}\left\{{ }^{31} \mathrm{P}\right\}$ experiment, observing the ${ }^{13} \mathrm{C}$ satellites of the tert-butyl protons in $\mathbf{1}(\mathbf{A})$. Since ${ }^{13} \mathrm{C}$ is the passive nucleus, the signs of ${ }^{1} J\left({ }^{13} \mathrm{C}^{1} \mathrm{H}\right)(>\mathrm{O}[6])$ and ${ }^{3} J\left({ }^{31} \mathrm{P}^{13} \mathrm{C}\right)$ are compared and shown to be alike. Furthermore, three ${ }^{13} \mathrm{C}\left\{{ }^{1} \mathrm{H}\right\}$ or ${ }^{1} \mathrm{H}\left\{{ }^{13} \mathrm{C}\right\}$ experiments are necessary. These experiments are most readily conducted as two-dimensional $(2 \mathrm{D}){ }^{13} \mathrm{C} /{ }^{1} \mathrm{H}$ heteronuclear shift correlations [7], based on $\left.{ }^{1} J\left({ }^{13} \mathrm{C}^{1} \mathrm{H}\right)(\mathbf{B}),{ }^{2} J^{13} \mathrm{C}^{1} \mathrm{H}\right)(\mathbf{C})$ and ${ }^{3} J\left(\equiv{ }^{13} \mathrm{C}^{1} \mathrm{H}\right)(\mathbf{D})$. This type of experiment has already proved extremely helpful for determining signs of coupling constants [8]. It is very fast ( $\mathrm{ca}$. 5 to 10 minutes) because of the small sweep width usually required in $F_{1}\left({ }^{1} \mathrm{H}\right)$ (see experimental part), and it is much more efficient, particularly in the case of small long range couplings ${ }^{n} J\left({ }^{13} \mathrm{C}^{1} \mathrm{H}\right)($ see $\mathbf{C}, \mathbf{D})$, than one-dimensional selective ${ }^{13} \mathrm{C}\left\{{ }^{1} \mathrm{H}\right\}$ or ${ }^{1} \mathrm{H}\left\{{ }^{13} \mathrm{C}\right\}$ experiments. Taking into account the result of experiment $\mathbf{A}$, it follows from $\mathbf{B}$ that ${ }^{4} J\left({ }^{31} \mathrm{P}^{1} \mathrm{H}\right)>\mathrm{O}$. This can be used in $\mathbf{C}$ and $\mathbf{D}$ to obtain the absolute positive signs of the coupling constants ${ }^{2} J\left({ }^{31} \mathrm{P}^{13} \mathrm{C}\right)$ and ${ }^{1} J\left({ }^{31} \mathrm{P} \equiv{ }^{13} \mathrm{C}\right)$, respectively.
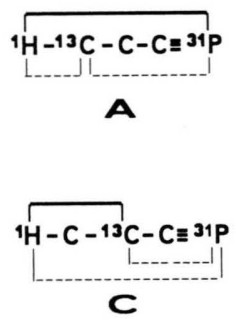

Scheme 1.

Relevant spin systems of the phosphaalkyne 1; bold drawn lines connect nuclei which are either irradiated or observed and thin broken lines show which coupling constants are to be compared with respect to their sign.

A: ${ }^{1} J\left({ }^{13} \mathrm{C}^{1} \mathrm{H}\right) /{ }^{3} J\left({ }^{31} \mathrm{P}^{13} \mathrm{C}\right)>\mathrm{O}$; since ${ }^{1} J\left({ }^{13} \mathrm{C}^{1} \mathrm{H}\right)>\mathrm{O}$, it follows that ${ }^{3} J\left({ }^{31} \mathrm{P}^{13} \mathrm{C}\right)>\mathrm{O}(+6.0 \mathrm{~Hz})$.

B: ${ }^{3} J\left({ }^{31} \mathrm{P}^{13} \mathrm{C}\right) /{ }^{4} J\left({ }^{31} \mathrm{P}^{1} \mathrm{H}\right)>\mathrm{O}$; it follows from $\mathbf{A}$ that ${ }^{4} J\left({ }^{31} \mathrm{P}^{1} \mathrm{H}\right)>\mathrm{O}(+0.9 \mathrm{~Hz})$.

C: ${ }^{4} J\left({ }^{31} \mathrm{P}^{1} \mathrm{H}\right) /{ }^{2} J\left({ }^{31} \mathrm{P}^{13} \mathrm{C}\right)>\mathrm{O}$; it follows from $\mathbf{B}$ that ${ }^{2} J\left({ }^{31} \mathrm{P}^{13} \mathrm{C}\right)>\mathrm{O}(+18.2 \mathrm{~Hz})$.

D: ${ }^{4} J\left({ }^{31} \mathrm{P}{ }^{1} \mathrm{H}\right) /{ }^{1} J\left({ }^{31} \mathrm{P} \equiv{ }^{13} \mathrm{C}\right)>\mathrm{O}$; it follows from $\mathbf{B}$ that ${ }^{1} J\left({ }^{31} \mathrm{P} \equiv{ }^{13} \mathrm{C}\right)>\mathrm{O}(+38.5 \mathrm{~Hz})$. 
Clearly, these results provide a firm basis for the discussion of changes in the magnitude of ${ }^{1} J\left({ }^{31} \mathrm{P} \equiv{ }^{13} \mathrm{C}\right)$ in phosphaalkynes. The previous conclusions [4] are shown to be correct. The knowledge of the positive sign of ${ }^{1} J\left({ }^{31} \mathrm{P} \equiv{ }^{13} \mathrm{C}\right)$ in 1 should also stimulate to test computational schemes [9] with respect to the respective contributions of mechanisms of spin-spin coupling.

\section{Experimental}

Compound 1 was prepared as described [1, 3d, 10], dissolved in $\mathrm{C}_{6} \mathrm{D}_{6}(\mathrm{ca} \cdot 10 \% \mathrm{~V} / \mathrm{V})$ in a $5 \mathrm{~mm}$ (o.d.) tube, degassed by several pump freeze/thaw cycles and sealed. All measurements were carried out at $27 \pm 1{ }^{\circ} \mathrm{C}$. The ${ }^{1} \mathrm{H}\left\{{ }^{31} \mathrm{P}\right\}$ experiments have been carried out using a BRUKER WP 200 spectrometer, equipped with a second frequency synthesizer and a selective amplifier. The correct pow- er level for ${ }^{31} \mathrm{P}$ irradiation was checked for the main signal $\left({ }^{4} J\left({ }^{31} \mathrm{P}^{1} \mathrm{H}\right)=0.9 \mathrm{~Hz}\right)$ before the ${ }^{13} \mathrm{C}$ satellites were recorded with simultaneous ${ }^{31} \mathrm{P}$ irradiation at higher or lower frequency with respect to the central ${ }^{31} \mathrm{P}$ resonance. The $2 \mathrm{D}{ }^{13} \mathrm{C} /{ }^{1} \mathrm{H}$ heteronuclear shift correlations were performed using a BRUKER AC 300 instrument. The spectral widths were $2 \mathrm{~Hz}\left(F_{l}\right)$ and $200 \mathrm{~Hz} / 1 \mathrm{~K}$ data points $\left(F_{2}\right) ; 8$ experiments of 8 scans (recycle time $6 \mathrm{~s}$ ) each gave a sufficient signal-to-noise ratio after zero-filling and Gaussian multiplication in both dimensions ( $c a .12$ minutes of spectrometer time). The coupling constants ${ }^{n} J\left({ }^{13} \mathrm{C}^{1} \mathrm{H}\right)$ serving for polarization transfer in the $2 \mathrm{D}$ experiments were 130 $\mathrm{Hz}(n=1), 4.4 \mathrm{~Hz}(n=2)$ and $4.8 \mathrm{~Hz}(n=3)$.

Support of this work by Deutsche Forschungsgemeinschaft and Fonds der Chemischen Industrie is gratefully acknowledged.
[1] G. Becker, G. Gresser and W. Uhl, Z. Naturforsch. 36b, 16 (1981).

[2] a) M. Regitz and P. Binger, Angew. Chem. 100, 1541 (1988); Angew. Chem., Int. Ed. Engl. 27, 1484 (1988);

b) M. Regitz, in M. Regitz and O. Scherer (eds): Multiple Bonds and Low Coordination in Phosphorus Chemistry, pp. 58-111, Thieme, Stuttgart (1990).

[3] a) S. P. Anderson, H. Goldwhite, D. Ko, and A. Letsou, J. Chem. Soc. Chem. Commun. 1975, 744;

b) R. Appel, G. Maier, H. P. Reisenauer, and A. Westerhaus, Angew. Chem. 93, 215 (1981); Angew. Chem., Int. Ed. Engl. 20, 197 (1981);

c) R. Appel and A. Westerhaus, Tetrahedron Lett. 1981, 2159;

d) W. Rösch, U. Vogelbacher, T. Allspach, and M. Regitz, J. Organomet. Chem. 306, 39 (1986);

e) B. Pellerin, J.-M. Denis, R. Perrocheau, and R. Carrie, Tetrahedron Lett. 1986, 5723;

f) E. P. O. Fuchs, M. Hermesdorf, W. Schnurr, W. Rösch, H. Heydt, M. Regitz, and P. Binger, J. Organomet. Chem. 338, 329 (1988);

g) R. Appel and M. Poppe, Angew. Chem. 101, 70 (1989); Angew. Chem., Int. Ed. Engl. 28, 53 (1989).

[4] B. Wrackmeyer, Z. Naturforsch. 43b, 923 (1988).

[5] a) W. McFarlane and D. S. Rycroft, Annu. Rep. NMR Spectrosc. 9, 319 (1979); b) W. McFarlane, Annu. Rep. NMR Spectrosc. 5A, $353,1972$.

[6] C. J. Jameson, in J. Mason (ed.): Multinuclear NMR, pp. 89-131, Plenum Press, New York (1987).

[7] G. E. Martin and A. S. Zektzer, Two-Dimensional Methods for Establishing Molecular Connectivity, pp. 213-380, VCH Publishers, Weinheim (1988).

[8] a) A. Bax and R. Freeman, J. Magn. Reson. 45, 177 (1981);

b) V. Rutar, Chem. Phys. Lett. 106, 258 (1984);

c) T. C. Wong, J. Magn. Reson. 63, 179 (1985);

d) B. Wrackmeyer and K. Horchler, Magn. Reson. Chem. 28, 56 (1990);

e) B. Wrackmeyer and H. Zhou, Magn. Reson. Chem. 28, 1066 (1990);

f) $\bar{E}$. Kupče and B. Wrackmeyer, Magn. Reson. Chem. 29, 351 (1991);

g) B. Wrackmeyer, E. Kupče, and A. Schmidpeter, Magn. Reson. Chem. 29, 1045 (1991).

[9] J. Kowalewski, Annu. Rep. NMR Spectrosc. 12, 82 (1982).

[10] a) G. Becker, W. Becker, R. Knebl, H. Schmidt, U. Weber, and M. Westerhausen, Nova Acta Leopold. 59, 55 (1985);

b) M. Regitz, W. Rösch, T. Allspach, U. Annen, K. Blatter, J. Fink, M. Hermesdorf, H. Heydt, U. Vogelbacher, and O. Wagner, Phosphorus, Sulfur 30, 479 (1987). 